\title{
REFLEXÓES SOBRE O NINGUÉM \\ NA OBRa DE HANNAH ARENDT
}

\section{Vanessa Sievers de Almeida ${ }^{1}$}

\begin{abstract}
Resumo: Em sua obra As origens do totalitarismo, Hannah Arendt afirma que os regimes totalitários evidenciaram que é possível transformar pessoas em seres supérfluos, isto é, elementos substituíveis e descartáveis. Já em seus escritos tardios, como os da coletânea Responsabilidade e julgamento, a pensadora se refere ao ninguém, um ser humano que deixou de ser uma pessoa. Assim, embora sob diferentes designaçôes, o ninguém aparece em vários pontos de sua obra. Neste artigo, procuro compreender essa figura, estabelecendo contrapontos com a figura do alguém, ou do quem, e com a do "egoísta". Arendt mesma não usa o termo "egoísta", mas é possível pensar que a distinção entre ele e o ninguém ajuda a caracterizar o último com maior nitidez, como um fenômeno próprio da sociedade de massa, em especial dos regimes totalitários. Espero mostrar como as figuras extremas do ninguém e do alguém e, em algum ponto entre os extremos, a do egoísta se tornam profícuas, não só para compreender algumas experiências analisadas por Arendt, mas também para pensar sobre as nossas.
\end{abstract}

Palavras chaves: Hannah Arendt. Ninguém. Alguém. Massa. Totalitarismo.

\section{INTRODUÇÃo}

Em fevereiro de 1955, Hannah Arendt (2002, p. 520, tradução nossa, grifo da autora) escreve, em seu Diário de pensamento:

Por que, afinal, existe Alguém e não Ninguém? Isso é $a$ questão da política. [...] O Alguém está aí para guardar a criação; o Ninguém pode destruíla. Quando a tivermos destruído e formos indagados, responderemos: Ninguém o fez. O deserto do Nada, povoado pelo povo dos Ninguéns.

${ }^{1}$ Universidade Federal da Bahia (UFBA), Salvador, BA - Brasil. https://orcid.org/0000-0002-

7820-9504 E-mail: vanessa.sievers.a@gmail.com

https://doi.org/10.1590/0101-3173.2021.v44n3.29.p375

\section{(i)}


Quando a criação for destruída, somente poderemos dizer: "Ninguém o fez". Essa resposta é estranhamente ambígua: primeiro, ela nos diz que o ato da destruição de tudo que conhecemos não tem sujeito ou autor e, assim, não há culpado nem responsável. Não haverá quem possa prestar contas do ocorrido. Afinal, "ninguém o fez" quer dizer que "nenhuma pessoa o fez". Não obstante, terão sido homens e mulheres que o fizeram, seres humanos. "Ninguém o fez", portanto, significa também que os feitores, embora sejam seres humanos, não se constituem como pessoas, mas são ninguém ou o povo dos ninguéns.

Esses seres estranhos aparecem sob outros nomes, na obra de Arendt: seres supérfluos, dentes da engrenagem, homens da massa, elementos de uma espécie; há também os mortos-vivos, coisas, que não se assemelham a animais, mas a marionetes. Em todos os casos, embora por razóes distintas, nós nos deparamos aqui com o ninguém. O ninguém não aparece no palco do mundo, mas também não é capaz de algo muito mais elementar como dizer "eu": "eu quero", "eu penso", "eu faço", "eu fiz" ou "farei”. É um ser incapaz de fazer qualquer coisa por iniciativa própria e, por conseguinte, deixou de ser um "eu”. O que assusta é que, apesar dessa estranha ausência de memória, pensamento e ação, esse povo dos ninguéns pode fazer coisas terríveis, pode chegar a destruir a criação, como Arendt anota, em seu diário.

A essas versôes do ninguém Arendt opõe o alguém, também chamado por ela de quem. Ele é descrito, em especial, em $A$ condição humana, no belíssimo capítulo sobre a ação: é a pessoa, que, por iniciativa própria, se insere no mundo humano, agindo e falando, e assim se revela em sua singularidade, respondendo à pergunta "Quem és?" (ARENDT, 2010, p. 223), que o mundo lhe faz. Esse quem, no final, terá uma estória ${ }^{2}$ que poderá ser narrada e pela qual será lembrado.

O tema não se esgota nesses textos e não pretendo abordá-lo em todos seus desdobramentos. No que segue, refletirei sobre algumas características do ninguém que se destacam no pensamento de Arendt e que talvez nos ajudem a pensar sobre alguns fenômenos da atualidade, especialmente alguns comportamentos que nos deixam perplexos. Como compreender, por exemplo, o fato de muitas pessoas seguirem, com entusiasmo, propostas claramente contrárias a seus interesses? Como é possível dizer e defender publicamente o

2 Para manter a distinção que Arendt faz entre story e history, usaremos os termos "estória" e "história" respectivamente, seguindo a tradução revisada por Adriano Correia de $A$ condição humana (ARENDT, 2010). 
absurdo? Por que as pessoas se tornam cegas, não só em relação a um mundo compartilhado, mas com respeito a seus interesses pessoais? Essa cegueira também toma conta de nós? Em que medida estamos dispostos a negar quem somos, para funcionar em processos desgastantes e sem sentido, aos quais nos submetemos, às vezes abrindo mão de cuidar até do mais urgente, o mínimo de bem-estar, sem o qual não sobrevivemos? A partir dessas indagaçóes, retomarei algumas reflexões de Hannah Arendt que me parecem instigantes, em vista do momento atual.

\section{O ALGUÉM E O NINGUÉM COMO POLOS OPOSTOS}

As figuras do alguém e do ninguém aparecem, com essa ou outra designação, nas reflexóes de Arendt sobre experiências políticas. É importante salientar que a autora não elabora, com isso, uma ideia ou um "esquema" (ARENDT, 2004b, p. 210) abstrato, o qual possa ser aplicado para avaliar personagens, atos ou acontecimentos históricos. Também não se trata de um método de classificação, como se pudéssemos simplesmente dividir os seres humanos em ninguéns e alguéns. É, muito mais, uma tentativa da pensadora de julgar as experiências de seu tempo e de se posicionar, não com base num padrão geral, mas com o auxílio de exemplos. As experiências históricas escolhidas evidentemente representam casos particulares, os quais, porém, podem nos ajudar a pensar sobre outros casos, sem pretensôes de chegarmos a julgamentos de validade universal. Nesse sentido, não há regras gerais a serem aplicadas, mas pode haver "sinais de orientação" (ARENDT, 2004b, p. 210) que nos assistem, quando examinamos atos e acontecimentos.

Dando um passo além disso, penso que as figuras do ninguém e do alguém como "sinais de orientação" podem se tornar profícuas, se as imaginarmos como dois polos extremos, entre os quais há uma variedade de formas de vida. Proponho, portanto, um "exercício de pensamento" (ARENDT, 1990, p. 41), a partir de Arendt, mas caminhando por conta própria, na tentativa de colocar em movimento a reflexão sobre as experiências analisadas por Arendt e também sobre as nossas.

Pretendo pensar as figuras como se estivessem ocupando posiçôes extremas, às quais nossas experiências podem se aproximar ou das quais se distanciam, em maior ou menor medida. No polo do alguém está a pessoa que age e que, ao se inserir no espaço público, poderá revelar quem ela é. Ser alguém pressupóe, portanto, um espaço compartilhado com outras pessoas, 
cuja presença nos impele a interagir com elas. Nossos atos e palavras se dirigem aos outros, que veem o que fazemos e ouvem o que dizemos. Tudo isso depende da nossa iniciativa, porque precisamos dar o primeiro passo para participar do espaço comum e, por isso, requer coragem por não sabermos de antemão como os outros irão reagir à nossa fala, nem controlarmos totalmente os nossos próprios atos. É, contudo, nesses encontros e desencontros, ao intervir no mundo, ao se mostrar e ver os outros, que a pessoa vem a ser alguém.

Assim como nas estórias de ficção, há um suspense na estória de vida de cada um, porque náo conhecemos o final. Por isso, Arendt afirma que somente quando a vida chega a seu fim saberemos realmente quem a pessoa foi. Cada estória é imprevisível, porque somos livres e, ao mesmo tempo, sujeitos às circunstâncias e aos acontecimentos. Não se pode prever um percurso de vida como se fosse a execução de um plano preestabelecido, nem se pode dizer quem alguém é, antes de sua inserção no mundo. Finalmente, a estória de cada um ganhará seu sentido na retrospectiva, quando poderá ser lembrada e narrada como uma trajetória única que, junto a outras, compõe a história do mundo comum, que, por sua vez, é táo ou talvez ainda mais imprevisível do que as estórias singulares.

Contudo, mostrar quem somos, por meio de atos e palavras e, assim, participar da história do mundo e talvez sermos lembrados como alguém que se distinguiu, é uma possibilidade de ação e de liberdade política que existiu em plenitude apenas em poucas experiências históricas. Assim, Arendt (1990, p. 217) explica que "[...] os períodos de existência livre foram sempre relativamente curtos na história da humanidade.” Porém, é entre esses momentos significativos que Arendt escolhe algumas experiências ${ }^{3}$ que considera exemplares, como a pólis grega, na qual os meros mortais acreditavam que, através de atos e palavras, poderiam ganhar algo da imortalidade que estava reservada aos deuses e, desse modo, sobreviveriam na pólis à sua própria morte (ARENDT, 2010).

Outra fonte de inspiração são os revolucionários da era moderna, os quais, na leitura de Arendt, se espantaram ao perceber que realmente estavam mudando o mundo, vendo-se diante do assustador abismo da liberdade

3 É importante destacar que se trata de experiências, que, em nenhum momento, são tidas como perfeitas, como se pudessem ser elevadas a ideais. Em suas análises, Arendt nấo suprime os aspectos negativos das experiências exemplares, porém, insiste em que nossa inspiração deve vir de experiências políticas e náo de ideias ou teorias, elaboradas no gabinete de um pensador ou cientista, os quais certamente não precisam lidar com o inconveniente das imperfeiçóes que qualquer experiência histórica revela. 
(ARENDT, 1993; 2011). A pensadora também destaca os conselhos populares que se formaram, no decorrer das revoluçóes, para discutir e intervir no rumo da nova república (ARENDT, 2011). Em todos os casos, temos aqui pessoas que, extrapolando uma mera existência privada e participando da história do mundo, vêm a ser alguém.

Se esses momentos de liberdade são raros, pois a maior parte da história é composta por épocas de petrificação e de ruína (ARENDT, 1990), o que ainda permanece, mesmo na ausência de um espaço de participação política, são o dom da liberdade e a capacidade humana de agir. Quando ação e liberdade não podem se realizar plenamente, muitas vezes ainda podem se manifestar de outra forma, seja como resistência, seja ganhando expressão em outros espaços da existência.

No outro polo, temos o ser humano que deixa de ser uma pessoa, transformado num elemento supérfluo. Essa figura aparece na obra de Arendt, em suas análises e reflexôes sobre a sociedade moderna, em especial em sua análise dos regimes totalitários (ARENDT, 1989), os quais transformaram pessoas em elementos substituíveis e descartáveis, como veremos mais adiante. Esses ninguéns estão no polo oposto do alguém, mas entre esses polos encontramos as mais diversas experiências e formas de existência. ${ }^{4}$ São figuras que náo necessariamente se caracterizam como um alguém ou um ninguém, todavia, estão em algum ponto entre esses polos.

No que segue, abordarei uma figura que denominarei "egoísta" e que me interessa por se situar entre os polos, e não no polo do ninguém, como à primeira vista poderíamos pressupor.

\section{EGOÍSTA E O NINGUÉM}

Em sua análise da Revolução Americana, Arendt (2011) chega à conclusão de que a revolução fracassou em grande parte, porque entre os cidadãos prevaleceu a opção pela felicidade privada. Eles passaram a antepor seus interesses privados à experiência da felicidade pública, proporcionada

\footnotetext{
${ }^{4} \mathrm{Na}$ obra de Arendt aparecem, por exemplo, aqueles que foram excluídos do mundo, mas encontraram formas alternativas de existência; os que lutaram para mudar o mundo, mesmo não tendo espaço nele, os poetas e escritores, que, às vezes, eram a única luz que sobrava; os filósofos, que desprezaram a política; os cristãos antimundanos; os santos e os criminosos que permanecem no escuro; os parvenue e sua tentativa apolítica de sobreviver; os párias, rebeldes ou não, e outros personagens que revelam os mais diversos modos de vida. São figuras que não necessariamente se caracterizam como um alguém ou um ninguém, embora algumas talvez possam se aproximar de um dos polos.
} 
pelo engajamento político. A autora relata que, segundo a análise de Thomas Jefferson, um dos pais fundadores, o desinteresse nas questóes políticas podia ser explicado pela ausência de espaços de participação. A Constituição, a qual previa a eleição de representantes, mas não a atuação política direta dos cidadãos, acabou por restringir essa possibilidade a alguns poucos, enquanto a maioria se preocupava com os assuntos públicos somente no momento em que depositava seu voto na urna. A ausência de espaços para a participação política efetiva dos cidadáos tolheu-lhes a felicidade pública de poder debater e decidir junto a seus iguais sobre os rumos do mundo compartilhado.

Nesse ponto, Arendt (2011. p. 318) parece estar em sintonia com Jefferson:

O que ele [Jefferson] viu como um perigo mortal para a república foi que a constituição dera todo o poder aos cidadãos sem lhes dar a oportunidade de ser republicanos e de agir como cidadãos. Em outras palavras, o perigo era que todo o poder fora dado ao povo em sua qualidade privada e náo se estabelecera um espaço para o povo em sua qualidade de cidadania.

No final, a busca da felicidade privada se sobrepóe ao compromisso público, ou, em outras palavras, a prosperidade é posta acima da liberdade política e da preocupaçáo com o mundo comum. Perde-se o "espírito revolucionário", quando o cidadão da revolução se transforma no indivíduo privado, o qual busca se ver livre do fardo da política para se dedicar exclusivamente a seus interesses.

Esse indivíduo, o citoyen transformado em bourgeois, o cidadão que se torna burguês, se comporta como um egoísta, isto é, como alguém que coloca seu interesse privado acima de qualquer compromisso com o mundo público, todavia - e esse é o ponto que me importa aqui - náo é um ninguém. Tratase de alguém que tem um objetivo claro e procura realizar seus propósitos. Possivelmente, é movido por uma paixão, como, por exemplo, a que Arendt (2011, p. 184) menciona, citando o juiz Pendleton: “[...] a paixão fatal pelas riquezas rápidas" que sempre tende a "[...] extinguir todos os sentimentos de dever político e moral."

Contudo, é decisivo que o egoísmo ou a mentalidade burguesa, seja a de um burguês, seja de alguém que quer sê-lo, não transformam a pessoa em um ninguém. $\mathrm{O}$ ninguém não é o egoísta, assim como o alguém não se qualifica pelo altruísmo. Não se trata de uma questão moral no sentido corrente do 
termo, tanto que, para Arendt, a ação política não se define por critérios morais. $\mathrm{O}$ agente pode ser injusto e, mesmo assim, vir a ser um quem. Nesse sentido, "[...] a vida de um explorador [...] e a vida de uma parasita podem ser injustas, mas certamente são humanas." (ARENDT, 2010, p. 221). O explorador e o parasita ainda fazem algo por iniciativa própria. Embora seus atos possam ser moralmente reprováveis, há uma pessoa que diz "eu quero" ou "é do meu interesse" e que atua, tendo em vista seus propósitos. Na sua existência há um “eu”, e seu fazer não é desprovido de motivos, vontade ou finalidade. É uma figura que podemos compreender, mesmo que não aprovemos seus atos.

$\mathrm{O}$ egoísta se distingue do ninguém, porque este último, como veremos, deixa de dizer "eu quero" ou "eu faço isso para obter aquilo". Nessa perspectiva, o modo de vida apolítico ou antipolítico, sem compromisso com qualquer coisa além de seus interesses privados, pode ser desprezível, mas não é necessariamente desprovido de iniciativa própria e não se torna incompreensível para o bom senso. Podemos muito bem entender a busca de felicidade privada, em parte, porque nós também procuramos essa felicidade, mesmo que náo necessariamente a coloquemos acima do compromisso público. Em outras palavras, o individualista, o egoísta ou o burguês não são o ninguém.

Nessa mesma direção vai a análise de Arendt (1989), em As origens do totalitarismo, quando explica que as massas modernas ganharam relevância somente com o colapso da sociedade de classes. Numa sociedade de classes, ainda havia interesses a serem defendidos, e cada classe tinha suas organizaçóes e seus partidos para advogar os seus. Quando grande parte da população não se vê mais representada pelos defensores daquilo que supostamente seria também a sua causa, e quando, na verdade, grandes grupos não têm mais interesses tangíveis, surge o fenômeno das massas. Se agir em benefício próprio é algo conhecido pela história e é algo compreensível, na sociedade moderna, surge algo diferente.

\section{O “HOMEM-DE-MASSA”}

Diferentemente do egoísta, o "homem-de-massa" (ARENDT, 1989, p. 365) pode, no extremo, se transformar num ninguém. A abordagem de Arendt sobre o surgimento das massas, no tempo que antecede os regimes totalitários, parece-me especialmente interessante, no momento atual. Nela, a autora busca compreender o fenômeno da massa, descrevendo algumas 
de suas características que vão se aguçando no percurso até o totalitarismo. Finalmente, sob o domínio total, a massa chega a ser composta por ninguéns.

$\mathrm{Na}$ terceira parte de As origens do totalitarismo, Arendt dedica um item ao tema das massas, referindo-se especialmente ao período entreguerras:

[...] o termo massa só se aplica quando lidamos com pessoas que, simplesmente devido ao seu número, ou à sua indiferença, ou a uma mistura de ambos, não se podem integrar numa organizaçáo baseada no interesse comum, seja partido político, organização profissional ou sindicato de trabalhadores. Potencialmente, as massas existem em qualquer país e constituem a maioria das pessoas neutras e politicamente indiferentes [...] (ARENDT, 1989, p. 361).

A massa, no período pré-totalitário, era composta por indivíduos que não se incorporavam a nenhum grupo e não tinham interesses determinados. Eram pessoas que não possuíam nenhum compromisso com o mundo ou suas instituiçôes; muitas sofreram os massacres da Primeira Guerra Mundial; grande parte estava na pobreza, devido à inflação e ao desemprego. Além disso, eram tomadas por desilusão e ódio contra o mundo e contra si mesmas e, assim, formavam "[...] a grande massa desorganizada e desestruturada de indivíduos furiosos que nada tinham em comum, exceto a vaga noção de que as esperanças partidárias eram vãs.” (ARENDT, 1989, p. 365).

Nesse contexto, Arendt (2003, p. 678, tradução nossa) aborda a "mentalidade específica das massas europeias" que surgiu "nessa atmosfera de desintegração geral”. Aos poucos, esses indivíduos não somente deixaram de se interessar pelo mundo, mas também por si mesmos. Num primeiro momento, o indivíduo se julgava por ter fracassado ou se compreendia como vítima, acusando o mundo de injustiça em relação a ele. Até então conservava, portanto, um olhar para si mesmo. Essa frustração, porém, não provocava nenhuma açáo ou reação, nem individual nem em conjunto, a qual pudesse defender seus interesses, quaisquer que fossem. Ao contrário, o fato de o mesmo destino ser o de muitos, a falta de perspectiva e a atomizaçáo produziram na pessoa a consciência de sua dispensabilidade. Assim, esse terrível descaso por si mesmo, de quem não se preocupa mais com seu próprio bem-estar, passa a caracterizar essa mentalidade. Nas palavras de Arendt (2003, p. 679, tradução nossa), “[...] o sentimento de que a própria pessoa não importava, que o 'eu' a qualquer momento e em qualquer lugar pode ser substituído por outro, tornou-se um fenômeno geral da massa.” 
Em consequência, surge nos homens da massa algo como uma indiferença não só em relação a seu papel no mundo, mas até quanto a seu próprio bem-estar. Não era o sentimento “[...] não tenho nada a perder, por isso posso ir para luta", contudo, o "[...] enfraquecimento do instinto da autoconservação” (ARENDT, 2003, p. 679, tradução nossa). De acordo com Arendt (1989, p. 365), “[...] ao perderem o interesse no próprio bem-estar, eles perdiam muito mais do que o sofrimento da miséria; perdiam a fonte das preocupaçôes e cuidados que inquietam e moldam a vida humana."

Esse vazio que fica deixava as pessoas suscetíveis a uma ideologia grandiosa, na qual a pessoa individual não contava, mas sim o destino da humanidade. Os indivíduos passavam a abrir mão de si mesmos, para se inserir no imponente futuro da espécie humana. Assinala Arendt (2003, p. 679-680, tradução nossa):

Himmler, que entendia, de modo notável, a mentalidade daqueles que devia organizar, descreveu náo apenas os seus membros da SS, mas as camadas do povo alemão das quais os recrutava, dizendo que não tinham interesse nenhum em "problemas do cotidiano", o que lhes interessava eram "questôes ideológicas" e "a grande felicidade de serem escolhidos para colaborar com uma missão que abrangia épocas históricas e cuja marca não podia perecer sequer em milhares de anos".

Essa fascinação pela grandiosidade, que é acompanhada por uma "[...] perda radical do interesse do indivíduo em si mesmo” (ARENDT, 1989, p. 366), é um fenômeno estranho. Se compararmos esse comportamento absurdo com a atitude egoísta de quem cuida exclusivamente de sua felicidade privada, esta última parece ser algo perfeitamente compreensível. Em oposição ao egoísta, o indivíduo que abre mão de si mesmo contraria o nosso bom senso, pois pressupomos que, mesmo na pior das situaçóes, a pessoa ainda terá um instinto de autoconservação. Logo, do ponto de vista do movimento totalitário, que depende da massa, a sociedade burguesa era um obstáculo:

$[\ldots]$ os movimentos totalitários [...] não podem tolerar o individualismo burguês ou qualquer outro tipo de individualismo. Os elementos apáticos da sociedade burguesa, por mais que relutem em assumir as responsabilidades de cidadãos, mantêm intacta a sua personalidade, pelo menos porque ela lhes permite sobreviver na luta competitiva pela vida. (ARENDT, 1989, p. 363). 
Porém, o movimento crescente na descrição do homem da massa de Arendt ainda continua. A perda de interesse na própria vida é seguida por uma espécie de torpor, de modo que nem o sofrimento acorda a pessoa de sua apatia. Assim, o desprezo pela própria vida leva finalmente a "[...] essa indiferença cínica ou entediada das massas frente à própria morte ou outras catástrofes pessoais" (ARENDT, 2003, p. 680, tradução nossa).

Em outras palavras, não é o egoísmo que caracteriza a massa, todavia, algo que o bom senso não esperaria. Segundo Arendt, há nela um aspecto altruista, algo capaz de eliminar o interesse pessoal e a preocupação com a própria sobrevivência. Contudo, não se trata de uma atitude idealista que coloca algum ideal acima do bem-estar próprio, porque "[...] o idealismo, tolo ou heroico, nasce da decisão e da convicção individuais." (ARENDT, 1989 p. 357). O homem da massa não faz escolhas nem tem convicçôes. O autoabandono não é a opção de abrir mão de alguma dimensão da existência para priorizar outra, e sim a disposição de desistir de si mesmo:

[...] o que é desconcertante no sucesso do totalitarismo é o verdadeiro altruísmo dos seus adeptos. É compreensível que as convicções de um nazista ou bolchevista não sejam abaladas por crimes cometidos contra os inimigos do movimento; mas o fato espantoso é que ele não vacila quando o monstro começa a devorar os próprios filhos, nem mesmo quando ele próprio se torna vítima da opressão [...] (ARENDT, 1989, p. 357).

Esse é um dos passos em direção ao movimento totalitário, o qual exige lealdade irrestrita, incondicional e inalterável de cada membro individual. Essa fidelidade tampouco deve ser confundida com convicçôes éticas ou políticas, já que o indivíduo não é fiel porque decide sê-lo, mas porque abriu mão de si mesmo para aderir ao movimento. Nas palavras de Arendt (1989, p. 373), a “[...] lealdade total só é possível quando a fidelidade é esvaziada de todo o seu conteúdo concreto, que poderá dar azo a mudanças de opinião.”

Desse modo, o totalitarismo depende da negação da individualidade e das capacidades de agir e pensar por conta própria. Conforme a ideologia nazista, era necessário desistir de si mesmo para fazer parte do fluxo natural ou morrer em favor dele. "Em Tischgespräche [Conversas à mesa], Hitler menciona várias vezes estar lutando por uma situação em que 'cada indivíduo sabe que vive e morre para a preservação da espécie” (ARENDT, 1989, p. 488) e proclama: "Uma mosca póe milhões de ovos, dos quais todos morrem. Mas as moscas ficam." (ARENDT, 1989, p. 488). 
Como é possível negar não somente o mundo, mas também a si mesmo? Para Arendt, um dos fatores, talvez o principal, que leva a essa visão distorcida da realidade e de si é a solidão que surge, quando a pessoa, embora possa estar inserida numa multidão, deixa de interagir ou mesmo de ter contato com outros. Dessa forma, a pessoa, apesar da presença de outros, náo é vista e tornase incapaz de se ver, assim como não mais se ouve, porque não é ouvida por outros. Essa solidão, o não falar com outros sobre o mundo e sobre si mesmo, tornou possível a perda do bom senso, a ponto do autoabandono, levando à crença em ideologias absurdas, mas grandiosas - que talvez transmitissem um senso de estar vivo, no meio à apatia e à indiferença diante de tudo e de si mesmo. Nesse sentido, Arendt (1989, p. 367) explica que a “[...] principal característica do homem da massa não é a brutalidade nem a rudeza, mas o seu isolamento e a sua fala de relaçoóes sociais normais.” A ausência da relação com outros está vinculada à ausência da relação consigo mesmo. Em seu Diário de pensamento, Arendt (2002, p. 141, grifos da autora) anota:

Com a dissolução do "eu", [ou seja,] com a moderna ausência do "eu" começa o jogo diabólico, porque, sem o "eu", não poderá ser estabelecido de forma alguma um contato com outros. [...] Psicologicamente, a ausência de contato é o estado em que todos os outros se tornaram supérfluos.

O problema é que essas pessoas indiferentes e sem interesses podem ser politicamente organizadas, por meio da ideologia e do terror. Se esses são os principais elementos do totalitarismo, a sua experiência básica é a solidão, de acordo com a análise de Arendt, na última parte de As origens do totalitarismo.

"Solidão não é estar só” (ARENDT, 1989, p. 528), mas é não ser visto por outros e não poder se ver; não falar com outros e não falar consigo mesmo:

O que torna a solidão táo insuportável é a perda do próprio eu, que pode realizar-se quando está a sós, mas cuja identidade só é confirmada pela companhia confiante e fidedigna dos meus iguais. Nessa situação, o homem perde a confiança em si mesmo como parceiro dos próprios pensamentos, e perde aquela confiança elementar no mundo que é necessária para que se possam ter quaisquer experiências. $\mathrm{O}$ eu e o mundo, a capacidade de pensar e sentir, perdem-se ao mesmo tempo. (ARENDT, 1989, p. 529).

A massa dos que não pensavam nem sentiam, que perderam o mundo e o "eu", se transformou no povo de ninguéns. Por isso, depois do desastre, a única resposta possível era: ninguém o fez. 


\section{Os CRIMINOSOS NAZISTAS QUE NÃO SÃO MONSTROS}

Entre os textos mais conhecidos de Arendt (2004a) que abordam a figura do ninguém está seu livro Eichmann em Jerusalém, no qual, pela primeira vez, usa o termo "banalidade do mal" para se referir a um mal cometido por ninguém. Esse tema é aprofundado em seus últimos escritos, entre os quais os textos publicados na coletânea Responsabilidade e julgamento. Aqui, o olhar da autora se volta para os indivíduos que consentiram com a barbárie, mas também para aqueles que se recusaram a participar. A autora, assim, retoma sua reflexâo sobre o ninguém e o alguém, indagando por que alguns estavam dispostos a cometer atrocidades e por que outros se negaram a fazê-lo.

O ponto de partida para sua abordagem, mais uma vez, é uma experiência, dessa vez os julgamentos pós-guerra. Esses eventos levaram Arendt a se questionar sobre decisóes individuais em situaçóes extremas: “[...] por que [a pessoa] consentiu em se tornar um dente na engrenagem [nazista]? $\mathrm{O}$ que aconteceu com sua consciência? Por que ela não funcionou ou por que funcionou ao contrário?” (ARENDT, 2004b, p. 353); e, no que concerne às pessoas, que não se ajustaram à sociedade nazista, ela pergunta: "[...] o que os impediu de agir como todos os demais?” (ARENDT, 2004b, p. 354).

Segundo Arendt, essas indagaçóes se inserem no campo dos assuntos morais, que, em princípio, dizem respeito "[...] às poucas regras e padróes segundo os quais os homens costumavam distinguir o certo do errado [...] e cuja validade supunha-se ser evidente para toda pessoa mentalmente sã como parte da lei divina ou natural." (ARENDT, 2004b, p. 113). O problema é que, com os acontecimentos do início do século XX, "[...] tudo isso desmoronou quase da noite para o dia" (ARENDT, 2004b, p. 113). Nesse contexto, em que as certezas derruíram e se perderam os critérios gerais para distinguir o certo do errado, Arendt questiona por que alguns resistiram ao regime, enquanto a grande maioria se adaptou tão facilmente à inversão de valores operada pela ideologia nazista.

A pensadora observa que os poucos que se recusaram a participar não alegaram princípios morais ou obediência a mandamentos divinos. Disseram que não precisaram refletir muito sobre sua decisão, pois, de imediato, estava claro para eles que lhes era impossível consentir. 
Aqueles que resistiram podiam ser encontrados em todas as esferas da vida, entre os pobres e inteiramente incultos, assim como entre os membros da boa e alta sociedade. Falavam muito pouco, e o argumento era sempre o mesmo. Não havia conflito, nem luta, o mal não era uma tentação. Não diziam que tinham medo de um Deus vingador e onividente, nem mesmo quando eram religiosos [...]. Eles simplesmente diziam: "Não posso, prefiro morrer", pois a vida não valeria a pena depois de ter praticado esses atos. (ARENDT, 2004, p. 354).

$\mathrm{O}$ que essas pessoas tinham em comum era que não lhes era possível passar de certo ponto, porque, depois disso, náo suportariam sua própria companhia, ou seja, sabiam que, caso cometessem determinados crimes, não poderiam mais se olhar no espelho: "[...] decidiram que seria melhor não fazer nada, não porque o mundo então mudaria para melhor, mas simplesmente porque apenas nessa condição poderiam continuar a viver consigo mesmos." (ARENDT, 2004, p. 107).

A recusa não teve nada de heroico, não estava relacionada à luta por um ideal, à fé ou a princípios; muito pelo contrário, a pessoa levava em conta a si mesma, visualizando seu próprio futuro. Desse modo, o critério aqui náo é "[...] o mundo, tampouco o seu aprimoramento ou mudança", mas "[...] o padrão é o eu" (ARENDT, 2004b, p. 143). O fato de ser testemunha de si mesmo e ter de conviver futuramente com a lembrança daquilo que se fez parece constituir algo como uma barreira moral. Assim, houve um limite para aquilo que essas pessoas consideravam possível.

É interessante que, no âmbito das decisões morais, reaparece a noção do quem, que podemos conhecer por meio de sua estória. Vimos antes que o mundo só saberá quem alguém foi quando puder narrar sua vida, ou seja, o quem se revela na sua plenitude somente na retrospectiva e na voz de outros. No caso daqueles que se recusaram a ter parte nas atrocidades do regime nazista, ressurge a relevância da estória, entretanto, dessa vez, é a estória que é antecipada pela imaginação. Trata-se aqui de uma narrativa sobre o que ainda não existe, isto é, a futura estória que é antevista na pergunta: "o que terei feito?" O limite moral surge com o temor de que, no futuro, a lembrança de seus próprios atos poderá ser insuportável.

O que assusta é que isso parece ser válido apenas para alguns. A grande maioria não resistiu ao regime nazista, mas se adaptou. Segundo Arendt, criminosos, como Eichmann, se recusaram a ser testemunhas de seus próprios 
atos, provavelmente porque não viam e não retomavam em sua mente o que fizeram e o que ocorreu. Quem não lembra se torna incapaz de pensar e refletir sobre os acontecimentos no mundo e sobre o seu papel neles. Esse medonho esquecimento elimina a linha divisória entre o possível e o impossível.

Se a lembrança pode trazer à presença aquilo que ocorreu, no pensamento, podemos entrar num diálogo conosco mesmos sobre aquilo que recordamos. Logo, quando pensamos, é como se nos dividíssemos em dois para nos dirigirmos a nós mesmos, perguntando e respondendo, procurando compreender os acontecimentos, recordando as próprias experiências e buscando um sentido para elas. No entanto, o caso dos criminosos nazistas parece mostrar que é possível se negar a lembrar e, pois, "[...] nunca começar o diálogo solitário silencioso que chamamos de pensar." (ARENDT, 2004b, p. 255):

Quem não conhece a interação entre mim e mim mesma (em que examinamos o que dizemos e o que fazemos) náo se importará em se contradizer, e isso significa que ele nunca será capaz de prestar contas do que diz ou faz, nem estará disposto e fazê-lo; tampouco se importará em cometer algum crime, pois pode estar seguro de que o ato será esquecido no momento seguinte. (ARENDT, 2004b, p. 255).

O malfeitor é incapaz de responder por seus atos. Ele não retoma em pensamento o que ocorreu no mundo e com os outros, como também não está disposto a olhar para seus próprios atos. De acordo com Arendt, essa estranha ausência de um "eu" ciente de seus atos se manifesta nas respostas que os próprios criminosos deram, nos tribunais:

O problema com os criminosos nazistas foi precisamente que eles renunciaram voluntariamente a todas as qualidades pessoais, como se não restasse ninguém a ser punido ou perdoado. Eles protestaram repetidas vezes, dizendo que nunca tinham feito nada por sua própria iniciativa, que não tinham tido nenhuma intenção, boa ou má, e que apenas obedeceram ordens. (ARENDT, 2004b, p. 177, grifos nossos).

Reencontramos aqui, nas reflexões tardias de Arendt, o ser humano que não se constitui como um "eu" e, com isso, a estranha ausência de um alguém que diz: "eu quero", "eu faço" ou "eu penso". O que assusta não é a maldade, mas a ausência de qualquer decisão ou vontade: 
[...] o maior mal perpetrado é o mal cometido por Ninguém, isto é, por um ser humano que se recusa a ser uma pessoa. [...] o malfeitor que se recusa a pensar por si mesmo no que está fazendo e que, em retrospectiva, também se recusa a pensar sobre o que faz, isto é, a voltar e lembrar o que fez (que é teshuvah, isto é, arrependimento), realmente deixou de se constituir como alguém. Permanecendo teimosamente um ninguém, ele se revela inadequado para o relacionamento com os outros que, bons, maus ou indiferentes, são no mínimo pessoas. (ARENDT, 2004, p. 177).

Esse tipo de malfeitor difere do criminoso, movido por vingança ou inveja, ou do egoísta que busca obter uma vantagem. O ninguém apenas consegue dizer: "fiz, mas não fui eu". Para Arendt, o caso dos criminosos nazistas mostra que "atos malignos" podem ser cometidos numa escala gigantesca, não porque houvesse alguém especialmente mau ou monstruoso, todavia, porque não houve um agente, isto é, uma pessoa que agiu; não havia nem mesmo motivos. Finalmente, não sobrou sequer uma pessoa para ser punida ou perdoada. É o mal sem rosto, sem nome e sem estória. Por isso, depois do desastre, apenas se pode afirmar "Ninguém o fez".

\section{ConsideraÇóes FinaIs}

O engajamento pelo bem comum desperta nosso apreço, em especial, quando vinculado a sacrifícios pessoais. Aplaudimos a ativista social ou o enfermeiro que luta contra a doença, e, assim como Hannah Arendt, admiramos aqueles que se engajam pelo mundo comum, colocando o seu próprio bemestar vital em segundo plano. Temos o altruísmo no sentido amplo da palavra - isto é, a atitude de quem visa ao bem do mundo ou do outro - como uma virtude. No entanto, a partir da reflexão sobre o alguém e o ninguém, essa chave de leitura perde em validade, na medida em que o ninguém, como o grande perigo que surge com a sociedade moderna, demonstra um altruísmo não admirável, mas tenebroso.

Dessa forma, a análise de Arendt nos provoca a julgar - com ela, mas também tendo em vista nossas experiências - sem recorrer a esses padróes tão familiares. Isso não significa necessariamente descartar por completo esses critérios, porém, é necessário considerar que pode haver comportamentos que escapam a eles, já que, por mais estranho que pareça, é possível que o desprendimento de si contribua para o mal, enquanto pode haver uma forma de egoísmo que se mostra saudável. Além disso, vimos que o ninguém - 
altruísta e, ao mesmo tempo, solitário e abandonado até por si mesmo - não é passivo nem inofensivo. Ele segue e se sacrifica por uma ideologia, se move e funciona como dente, grande ou pequeno, de uma engrenagem. A massa da sociedade moderna é formada por esses dentes que se póem em movimento.

No que nos diz respeito, pensamos que a tentativa de imaginar o ninguém e o alguém como polos, aos quais nos aproximamos em maior ou menor grau, nos provoca a questionar em que medida ainda podemos falar da massa em terceira pessoa, como geralmente nos apressamos a fazer. Ainda é plausível pressupor que nos mantemos como pensantes e agentes, na ausência de espaços de interação? Em que medida corremos o risco de nos movermos em direção ao polo do ninguém, por exemplo, quando recorremos a critérios prontos? Acrescenta-se a isso que, no contexto político no qual precisamos nos posicionar contra outros, náo podemos nos dar o luxo de repensar a cada momento nossa forma de julgar e nos deter num constante autoquestionamento. Desse modo, tendemos a continuar nas trilhas já andadas ou a seguir as opinióes de nosso grupo de referência.

Outro possível afastamento do polo do alguém está na frequente pretensão de poder funcionar na grande máquina produtiva e questioná-la, ao mesmo tempo. É razoável presumir que, ao satisfazer as exigências do funcionamento social, ainda temos tempo para agir e pensar e continuamos capazes de julgar? Vimos a perigosa ambiguidade do autossacrifício, que pode ser uma escolha com sentido, mas também pode levar ao desvanecimento da pessoa na massa. Em que medida estamos dispostos a abrir mão do mínimo de autoconservação, a qual, na verdade, poderia reter a nossa aproximação ao ninguém? Essa abnegação pode ter efeitos nocivos, como, por exemplo, o adoecimento. Nessa linha, a análise de Arendt nos desafia a indagar se as renúncias feitas são atos heroicos de quem escolhe sacrificar sua vida ou seu bem-estar por um ideal no qual acredita ou se são o comportamento de executores de tarefas que não escolheram e às quais não se opóem. $\mathrm{O}$ que perturba é justamente que o ninguém não é um monstro repulsivo, mas um ser que meramente funciona conforme padróes estabelecidos.

No polo oposto, Arendt tem para si o exemplo de Sócrates. Esse filósofo demonstrou coragem, não só porque questionava o que aparentemente estava posto, mas também porque escolheu como padrão o "eu" e não o mundo. Arendt salienta que, para Sócrates, a concordância consigo mesmo era mais importante do que a sintonia com o mundo: "Seria melhor para mim [...] que multidóes de homens discordassem de mim do que eu, sendo um só, estivesse em 
desarmonia comigo mesmo e me contradissesse." (PLATÃO apud ARENDT, 2004b, p. 249, grifos da autora). A autora afirma que esse pensar orientado no próprio "eu" pensante pode extrapolar o âmbito individual e ganhar relevância para o mundo, em situaçóes políticas de emergência. "Quando todo mundo é arrebatado sem pensar por aquilo que todos os demais fazem e acreditam, aqueles que pensam são puxados para fora de seus esconderijos porque a sua recusa a se juntar ao grupo é visível e, com isso, se torna uma espécie de ação." (ARENDT, 2004b, p. 256). No que nos concerne, fica a questấo se também nós estamos dispostos a entrar em conflito com "o mundo inteiro" e nos expor, para continuar em harmonia conosco.

A coragem, ressaltada por Arendt (1990, p. 203) como "[...] uma das virtudes políticas cardeais", é crucial também na relação conosco mesmos, a qual nos exige lembrar o que passou e examinar o que dissemos e fizemos. Além disso, essa relação nos faz viver sob o constante aviso de que cada ato ou decisão nossa poderá desencadear possíveis confrontos futuros conosco mesmos, ou seja, com esse "sujeito muito antipático" que não deixará de nos interrogar, quando "chegarmos em casa" e nos encontrarmos na nossa própria companhia. Quem pensa vive com a incômoda "[...] antecipação da presença de uma testemunha” (ARENDT, 2004b, p. 253). Por isso, há quem prefira evitar essa companhia.

Até o sofrimento carece de coragem, porque podemos deixar de ser testemunha de nosso próprio padecimento. A indiferença apática é, como vimos, uma das características do ninguém, disposto ao autossacrifício. No extremo, essa suposta ausência de sofrimento pode equivaler à perda do mobilizador da resistência. Arendt explica que os ninguéns se mostram como "[...] verdadeiros habitantes do deserto [totalitário]" (ARENDT, 2008, p. 267), quando passam a se sentir em casa nele. Assim, pode-se dizer que "[...] precisamente porque sofremos nas condições do deserto é que ainda somos humanos e ainda estamos intactos." (ARENDT, 2008, p. 267, grifo nosso). A capacidade de padecer nos preserva como pessoas e evita que nos transformemos em peças perfeitas da engrenagem.

Enfim, a coragem, em suas múltiplas facetas, talvez possa ajudar a dizer "não", quando for necessário. Esse "não" poderá ser dito por pessoas que se importam com sua estória, dispostos a conviver com o que fizeram ontem e a imaginar como viverão amanhã sendo testemunhas do que fizeram hoje, porque nossas estórias, passadas e futuras - as individuais e as compartilhadas

\footnotetext{
5 Essa proposição é atribuída a Sócrates, no Górgias de Platão.
} 
-, nos constituem como pessoas. O perigo é esquecermos que podemos ser protagonistas de uma estória, mesmo quando somos suas vítimas.

ALMEIDA, V. S. Reflections on the nobody in the work of Hannah Arendt. Trans/form/ ação, Marília, v. 44, n. 3, p. 375-394, Jul./Set., 2021.

\begin{abstract}
In her work The Origins of Totalitarianism Hannah Arendt asserts that totalitarian regimes have shown that it is possible to transform persons into superfluous beings, i.e., replaceable and disposable elements. In her late writings, like those in the compilation Responsibility and judgment, the thinker refers to the nobody, a human being who is no longer a person. Thus, although under different designations, the nobody appears at various points in her work. In this article I try to understand that figure, establishing counterpoints with the figure of the somebody, or the who, and with that of the 'egoist'. Arendt herself does not use the term 'egoist', but I think that the distinction between him and the nobody helps to characterize the latter more clearly, as a typical phenomenon of mass society, especially of totalitarian regimes. I hope to show how the extreme figures of the nobody and the somebody and, at some point between the extremes, that of the egoist become useful not only to understand some experiences analyzed by Arendt, but also to think about ours.
\end{abstract}

Keywords: Hannah Arendt. Nobody. Somebody. Mass. Totalitarianism.

\title{
REFERÊNCIA
}

ARENDT, H. Origens do totalitarismo. Tradução de Roberto Raposo. São Paulo: Companhia das Letras, 1989.

ARENDT, H. Entre o passado e o futuro. Tradução de Mauro W. Barbosa. 5. ed. São Paulo: Perspectiva, 1990.

ARENDT, H. A vida do espírito. Tradução de Antonio Abranches e Helena Martins. 2. ed. Rio de Janeiro: Relume Dumará, Ed. UFRJ, 1993.

ARENDT, H. Denktagebuch. Herausgegeben von Ursula Ludz, Ingeborg Nordmann. München: Piper, 2002, 2 Bde.

ARENDT, H. Elemente und Ursprünge totaler Herrschaft: Antisemitismus, Imperialismus, totale Herrschaft. 9. Aufl. München: Piper, 2003.

ARENDT, H. Eichmann in Jerusalem: ein Bericht von der Banalität des Bösen. Übersetzung von Brigitte Granzow. Einleitung von Hans Mommsen.13. Aufl. München: Piper, 2004a. 
ARENDT, H. Responsabilidade e julgamento. Edição de Jerome Kohn. Tradução de Rosaura Eichenberg. Revisão Técnica Bethânia Assy, André Duarte. São Paulo: Companhia das Letras, 2004b.

ARENDT, H. A promessa da política. Organização e introdução de Jerome Kohn. Tradução de Pedro Jorgensen Jr. Rio de Janeiro: Difel, 2008.

ARENDT, H. A condição humana. Tradução de Roberto Raposo. Revisão e apresentação de Adriano Correia. 11. ed. revista. Rio de Janeiro: Forense Universitária, 2010.

ARENDT, H. Sobre a revoluçáo. Tradução de Denise Bottmann. São Paulo: Companhia das Letras, 2011. 
ALMEIDA, V. S. 